\title{
$\mathrm{DSP}$ 를 적용한 전력용 $\mathrm{DC}$ 평활 커패시터의 이더넷 원격 고장진단시스템 개발
}

\section{A Development of Ethernet-Based Remote Diagnosis System for DC Voltage Smoothing Capacitor using DSP}

\author{
손 진 근 ${ }^{\dagger}$ \\ (Jin-Geun Shon)
}

\begin{abstract}
Electrolytic power capacitors today form essential components for virtually any power electronic system such as DC/DC converter or UPS. Frequently, electrolytic capacitors for DC link voltage smoothing are the key components which determine the life cycle of the whole unit and often are responsible for converter breakdown failures.

In this paper, ethernet-based remote diagnosis system for DC voltage smoothing capacitor using DSP control board is developed. To estimate the status of the capacitor, the equivalent series resistor(ESR) of the component has to be determined. The ESR detection scheme is based on the determination of the capacitor ripple power losses calculated from DC link voltage/current measurement. Experimental results show the veridity and reliability of the proposed ethernet-based remote on-line capacitor diagnosis system.
\end{abstract}

Key Words: Equivalent Series Resistance(ESR), Ethernet-Based Remote Diagnosis System, DC Link Electrolytic Capacitor, Power Electronic System. Ripple Power Losses.

\section{1. 서 론}

마이크로프로세서 및 전력전자 기술의 발달에 따라 컨버터/인버 터에 기반한 UPS 등 주문형 전력기기의 사용이 지속적으로 증가 하고 있다. 이러한 전력기기의 전력변환 시스템에서는 DC 링크부 에 에너지의 일시적 저장 및 전압 평활화를 위하여 비교적 대용량 이면서 가격이 저렴한 알루미늄 전해 커패시터를 거의 대부분 사용 하고 있다. 그러나 이러한 전해 커패시터는 열화 및 온도 상승에 따라 전해액의 증발이 가중되면서 폭발로 이어지는 사고가 빈번하 게 발생하게 되며, 이는 전력변환장치의 구성요소 중에서 사고의 비율의 약 $60[\%]$ 를 차지하고 있다고 보고되고 있다[1,2].

따라서 이러한 커패시터 고장사고는 단순한 부품사고 뿐 만 아니라 $\mathrm{PCB}$ 를 통한 단락사고에 의하여 전원라인의 사고 까지 이어지는 위험요소가 될 수 있으므로 이를 방지할 수 있는 진단 시스템의 개발이 필요하다. 지금까지 전해 커패 시터의 고장신호 진단기법은 전해 커패시터의 직렬저항(이하 ESR) 검출 기법이 대부분을 차지한다. Afroz M. Imam[3]은 커패시터의 맥동성분에 대한 전압/전류 신호를 스위칭 주파 수 영역대의 대역통과필터(BPF)에 의한 $\mathrm{FFT}$ 분석에 의하여 $\mathrm{ESR}$ 을 추정하는 기법을 제안하였으며, D.-C. Lee[4] 등은 커패시터의 맥동 전압/전류 성분을 신호처리하여 이를 RLS (recursive least squares)기법에 의하여 커패시터 ESR을 추 정하는 방식을 제안하는 등 이에 관한 연구가 활발히 진행

\footnotetext{
$†$ 교신저자, 정회원 : 경원대학교 전기공학과 교수· 공박 E-mail : shon@kyungwon.ac.kr
}

접수일자 : 2011년 4월 13일

최종완료 : 2011년 5월 24일
되고 있다.

본 연구에서는 각 전력변환장치마다 특정의 스위칭 주파 수를 미리 인지하여 그 주파수 영역에 맞는 $\mathrm{BPF}$ 의 신호처 리에 의한 기존의 $\mathrm{ESR}$ 추정 방법[5]을 피하고, 커패시터 리 플성분의 전력손실 개념에 의하여 스위칭 주파수의 인지없 이도 $\mathrm{ESR}$ 의 추정을 간단히 수행할 수 있는 기법에 의한 원 격의 모니터링 진단 시스템을 개발하였다.

개발된 전해 커패시터의 원격 진단시스템은 TI사에서 개 발한 TMS 320F28335의 DSP를 적용하여 LAN기반의 이더 넷 원격 네트워크 통신시스템을 구축하여 고장신호의 검출 데이터를 인터넷에 연결되어 있는 서버에서 원격으로 모니 터링 할 수 있는 기능을 지원하도록 하였으며, 또한 이의 시 스템이 여러 장소에 설치되어 있거나 원거리에 설치되어 있 는 경우에도 고장신호 데이터를 장소에 구애 받지 않고 감 시할 수 있도록 하였다. 또한 이의 커패시터 진단장비의 서 버 소프트웨어는 기본적으로 계측데이터의 그래픽 표시 기 능을 제공하며, 데이터 저장 기능 등을 통해 이력 조회 등이 가능하도록 하였다.

\section{2. 전해 커패시터의 특성과 고장 검출}

\section{1 전해 커패시터의 특성}

UPS나 인버터 등 각종 전력변환장치에서 알루미늄 전해 커패시터는 에너지의 일시적 저장 및 전압 평활용으로 많이 사용되는데 이는 전도성 극판의 한쪽을 전도성 재료인 전해 액(electrolyte)을 사용한다는 점이 주 특징이다. 특히 알루미 늄 전해커패시터의 양극판(anode foil)은 매우 높은 순도의 알루미늄 박 표면에 산화피막 $\left(\mathrm{AL}_{2} \mathrm{O}_{3}\right)$ 인 유전체(dielectric)로 
형성되어 있으며, 전해액과 전해지(separator), 그리고 음극 알루미늄 박(cathode foil)으로 구성되어 있다. 이때 화학적 방법에 의하여 생성된 산화피막은 매우 얇은 유천체 코팅으 로 정류성을 띄고 있으며, 음극에 이러한 산화피막을 채용하 면 무극성 커패시터의 구조를 가진다[3].

그림 1은 위의 구성 특성을 근거로 한 알루미늄 전해 커 패시터의 등가 모델을 나타낸 것이다. 여기서 커패시턴스 $\mathrm{C}$ 의 생성은 양극(anode \& cathode)에서 발생되고 내부 저항 $\mathrm{R}$ 은 전해액과 절연지의 저항으로 나타내며, $\mathrm{C}$ 와 병렬로 구성 되어 있는 $\mathrm{R}_{\mathrm{LC}}$ 는 전해액 누설 전류(leakage current)에 기인 하는 저항이며 $\mathrm{LESL}_{\mathrm{EL}}$ 등가직렬 인덕턴스를 나타낸 것이다.

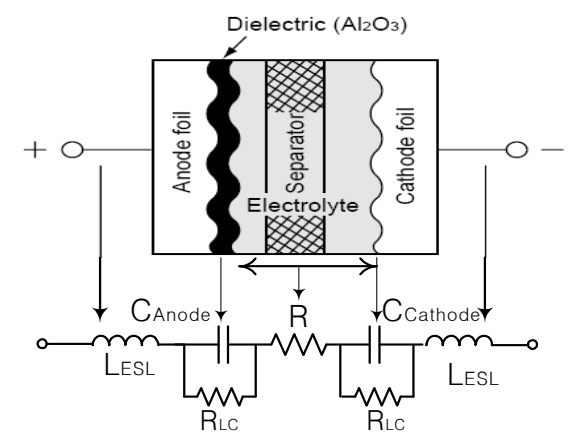

그림 1 전해 커패시터의 등가 모델

Fig. 1 Equivalent model of electrolytic capacitor.

그러나 이러한 전해 커패시터는 사용시간의 증가에 따라 열화가 진행되어 전해액의 분출 및 온도 상승 등으로 인하 여 많은 사고를 유발하게 된다. 전해 커패시터의 고장 모드 의 대부분은 전기화학적 반응에 의하여 나타나게 되는데 이 는 전해액의 감소 및 전해액 증기분출(vaporization), 양극과 음극에서의 커패시턴스 감소로 나타나게 되며 이의 요인으 로는 온도 및 전압 그리고 맥동전류 등의 초과에 의해서 발 생된다. 특히 온도의 초과는 전해액 성능과 직접 관련이 있 으며 기타 맥동 전류의 증가에 의하여 온도 상승을 가중시 키고 있음을 알 수 있다.

따라서 전해 커패시터의 고장 및 열화의 메커니즘은 온도 상승에 따른 전해액의 증발 $(\mathrm{dry}-\mathrm{up})$ 이 가장 큰 요인이며, 이 에 따라 정전용량의 감소 및 $\tan \delta$ (또는 $\mathrm{ESR}$ )의 증가를 초 래한다고 할 수 있으므로 커패시턴스의 정전용량 감소가 약 40[\%]이상으로 이어질 경우에는 이를 수명 말기로 판단하여 고장에 대비하게 된다[4,5].

\section{2 전해 커패시터의 ESR 추정기법}

그림 1 과 같은 전해 커패시터의 등가모델 구조에서 이의 복소 임피던스는 주파수변동에 따라 그 크기가 달라지게 되 며 또한 이의 값은 커패시터 ESR값에 지배적이라 할 수 있 다. 따라서 전해 커패시터의 고장신호 검출기법은 거의 대 부분 $\mathrm{ESR}$ 의 계측에 의하여 수행된다.

기존의 $\mathrm{ESR}$ 추정 알고리즘[5,6]은 거의 대부분 $\mathrm{BPF}$ 의 신 호처리기법에 의존하게 되는데 이는 각 전력변환 기기마다 특정의 스위칭 주파수를 미리 인지해야하는 불편함이 따르 게 되며 또한 이를 사전에 인지하지 못할 경우에는 필터의 대역 폭이 매우 커야 하므로 신호의 검출이 난해하다.

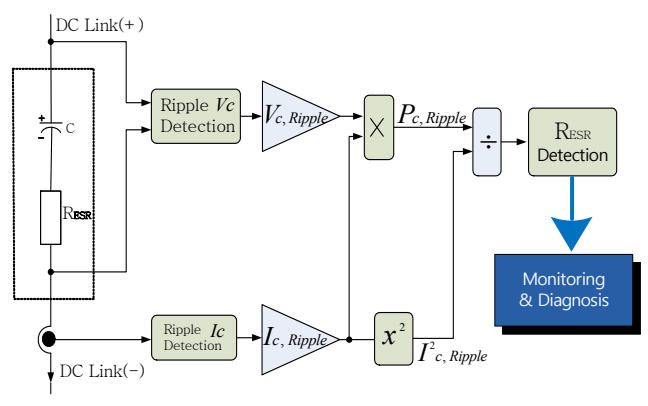

그림 2 전해 커패시터의 고장신호 검출기법

Fig. 2 Failure detection method of capacitor.

그림 2는 본 논문에서 사용한 전해 커패시터의 $\mathrm{ESR}$ 검출 에 대한 온라인 고장진단 알고리즘에 대한 블럭 다이어그램 을 나타내고 있다[6]. AC전원 소스로부터 $\mathrm{DC}$ 로 변환되는 정류기나 또는 SMPS에서 $\mathrm{DC}$ 부하전압의 평활화를 위해서 는 전해 커패시터가 사용된다. 그러나 이를 통과하는 커패 시터 입력전류 $I_{C}$ 는 거의 대부분 맥동성분의 신호가 포함하 게 된다. 이 때문에 이의 전류 $I_{C}$ 는 $\mathrm{DC}$ 성분의 옵셋 전류

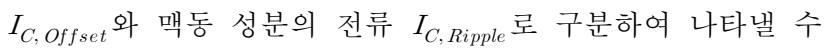
있고 이는 식 (1)과 같이 표현할 수 있다.

$$
I_{C}=I_{C, \text { Offset }}+I_{C, \text { Ripple }}
$$

이러한 전류신호 $I_{C}$ 에 대해서 $\mathrm{DC}$ 성분의 전류 $I_{C, \text { offset }}$ 를 제거하여 개방회로로 간주하고 맥동 성분을 별도로 신호처리 하면 전해 커패시터에서는 맥동 성분의 $I_{C, \text { Ripple }}$ 전류만이 커패 시터에 나타나게 되며 이를 전력 손실의 개념으로 간주하여 $\mathrm{ESR}$ 을 추정할 수 있다. 따라서 맥동 성분의 신호로부터 계산 된 전력손실 $P_{C, R i p p l e}$ 와 $I_{C, R i p p l e}^{2}$ 신호를 식 2 의 관계와 같이 나눗셈 연산하게 되면 $\mathrm{ESR}$ 의 평균값을 간단히 추정할 수 있게 된다. 이렇게 구해진 $\mathrm{ESR}$ 의 평균값은 $\mathrm{LPF}$ 에 의하여 적당히 대역의 폭을 제한하여 양질의 검출신호를 계측할 수 있다.

$$
R_{E S R} \approx \frac{P_{C, \text { Ripple }}}{I_{C, \text { Ripple }}^{2}}
$$

그러므로 전해 커패시터의 고장 검출은 미리 인지하거나 기준값으로 정한 $\mathrm{ESR}$ 값과 이의 추정 결과 값이 약 2 배 이 상일 경우에 커패시터의 열화에 대한 이상(abnormal) 징후 의 시작으로 판단하여 $\mathrm{ESR}$ 알람에 신호 전송하게 하며, 이 의 알람이 지속 반복되면 열화된 커패시터의 교체 등으로 사고를 미연에 방지할 수 있게 되는 고장진단 시스템이 되 게 된다.

\section{3. 원격 고장 진단시스템의 구성}

\subsection{DSP 제어보드의 구성}

본 연구에서는 포터블이 가능한 원격의 온라인 커패시터 진단장치의 개발을 위하여 TI사의 고성능 저전력 DSP 프로 세서인 TMS320F28335-150[MHz]를 적용하여 제어보드를 개발하였다. 이에 대한 $\mathrm{H} / \mathrm{W}$ 블럭 다이어그램 및 개발사양 을 각각 그림 3 과 표 1 에 나타내었다. 


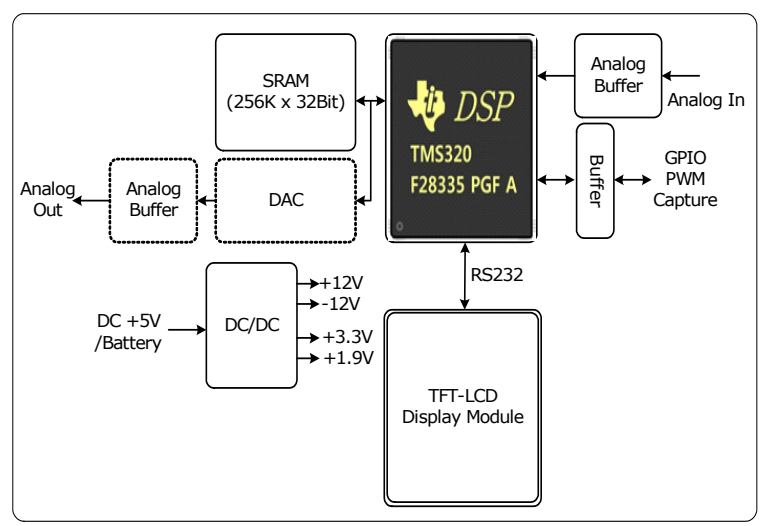

그림 3 커패시터 온라인 진단장치의 제어보드

Fig. 3 Control board of capacitor on-line diagnosis system.

표 1 진단장치 제어보드의 사양

Table 1 Spec. of capacitor diagnosis system board.

\begin{tabular}{|c|c|c|}
\hline 항목 & 사 양 & 내용 \\
\hline CPU & TMS320F28335 - 150[MHz] & Floating-Point지원 \\
\hline Memory & $\begin{array}{l}\text { Flash Memory - 512KBytes } \\
\text { SARAM - 64KBytes } \\
\text { SRAM - 1MBytes }\end{array}$ & $\begin{array}{l}\text { Flash, } \\
\text { SARAM - On Chip } \\
\text { SRAM - External }\end{array}$ \\
\hline Display & $\begin{array}{l}\text { Text LCD - C1604ABNHJH } \\
\text { Status LED - 6PCS }\end{array}$ & $\begin{array}{l}\mathrm{LCD} ; \\
20 \text { char } \times 4 \text { lines Text } \\
\mathrm{LED} ; \text {; 동작상태 } \\
\quad \text { 표시용 SMD }\end{array}$ \\
\hline 통신 & UART - 1Ch, CAN - 1Ch & $\begin{array}{l}\text { 외부 장비 연동 및 } \\
\mathrm{PC} \text { 모니터링용 통신 } \\
\text { 포트 }\end{array}$ \\
\hline$A D C$ & 12Bit $\times 16 \mathrm{Ch}$ & $\begin{array}{l}\text { Input Range : } \\
-5 \mathrm{~V} \sim+5 \mathrm{~V}\end{array}$ \\
\hline DAC & 12Bit $\times 8 \mathrm{Ch}$ & $\begin{array}{l}\text { Output Range : } \\
-5 \mathrm{~V} \sim+5 \mathrm{~V}\end{array}$ \\
\hline 전원 & $\begin{array}{l}\text { Input : DC 5V } \\
\text { Output : } 12 \mathrm{~V},-12 \mathrm{~V}, 3.3 \mathrm{~V}, 1.9 \mathrm{~V}\end{array}$ & On Board DC/DC \\
\hline
\end{tabular}

개발된 DSP 제어보드인 CPU TMS320F28335는 프로세 서의 다양한 기능에 비해 프로세서 외부의 핀 갯수가 한정 되어 있어서 하나의 핀에 다양한 기능들이 중복되어 있다. 따라서 DSP내부의 다양한 기능들을 동시에 사용하는 것은 어려우며, $\mathrm{DSP}$ 를 적용하여 개발하고자 하는 제품의 특성에 맞는 기능들을 사용할 수 있도록 핀을 할당하여 사용해야 한다. 본 연구에서 개발된 DSP보드는 커패시터 진단기능과 관련된 기능들은 핀을 할당하여 회로를 구성하였으며, 나머 지 핀들은 추후 다른 제품의 개발시에 소프트웨어적인 설정 만으로도 이용 가능하도록 회로를 구성하였다. 위의 $\mathrm{CPU}$ 내부에는 512[KBytes]의 플래시 메모리와 64[KBytes]의 $\mathrm{RAM}$ 을 내장하고 있어서 개발된 프로그램을 위한 공간은 충분하나, RAM영역이 부족하여 DSP 외부에 1 [MBytes] (256KWords x 32Bit)의 고속 SRAM을 추가로 확장함으로 써 데이터 처리 및 $\mathrm{DB}$ 구축시 공간이 충분하도록 하였다. 또한 시스템 운영시 전원이 꺼지더라도 지워져서는 안 되는 정보들을 보관하기 위한 목적으로 $32[\mathrm{Kbits}]$ 의 시리얼 플래 시 메모리를 장착 하였다.

\section{2 이더넷 원격진단}

본 연구에서 개발된 전해 커패시터의 진단 시스템은 계측 한 데이터를 인터넷에 연결되어 있는 서버에서 원격으로 모 니터링할 수 있는 기능을 지원하고 있으며, 이는 여러 장소 에 설치되어 있거나 물리적으로 원거리에 설치되어 있는 커 패시터 진단장비의 계측 데이터를 장소에 구애 받지 않고 감시할 수 있도록 하였다. 커패시터 진단장비의 서버 소프 트웨어는 기본적으로 계측데이터의 그래픽 표시 기능을 제 공하며, 데이터 저장 기능 등을 통해 이력 조회 등이 가능하 도록 하였다. 본 커패시터 진단장비의 서버 소프트웨어는 다음과 같은 특징을 갖게 하였다.

- TCP/IP통신을 통한 신뢰성 있는 데이터 통신을 수행

- 최대 256대의 커패시터 진단장비 동시 접속 기능

- 조회 데이터 종류 설정

- 최대 7 종류의 데이터 실시간 감시 가능

- 최대 3 종류의 데이터 그래프 표시 기능

- 데이터 저장 기능

- 통신 데이터 모니터링 기능

이때의 커패시터 진단장비의 서버 소프트웨어의 화면 구 성에 대한 커패시터 진단장비의 설정 화면은 그림 4 와 같다. 이는 서버 프로그램에 접속되어 있는 커패시터 진단장비의 설정 화면이며, 조회할 데이터의 종류 및 조회 주기 등을 설 정하는 기능을 수행한다. 그림 5 는 이더넷 통신을 이용한

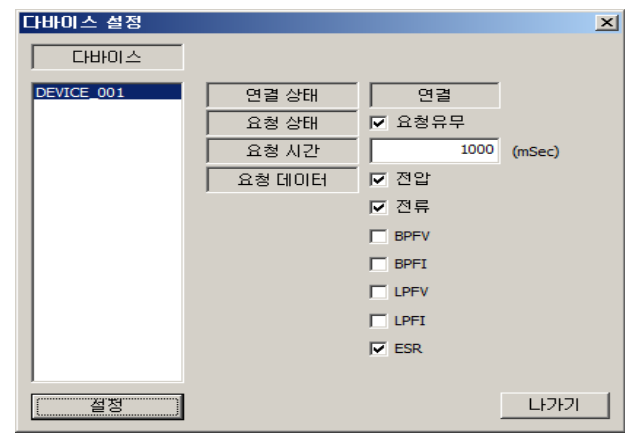

그림 4 진단 장비의 서버 소프트웨어의 설정 화면

Fig. 4 Server $\mathrm{s} / \mathrm{w}$ setting mode of diagnosis system.

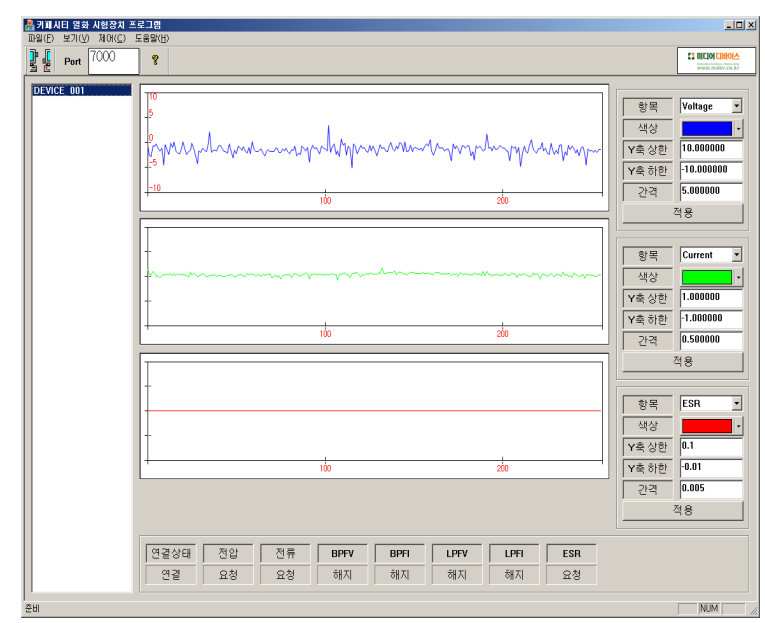

그림 5 이더넷 통신을 이용한 모니터링 소프트웨어

Fig. 5 Monitoring $\mathrm{s} / \mathrm{w}$ display using ethernet interface. 
모니터링 소프트웨어 동작 화면을 나타낸 것이다. 서버 소프트웨어는 커패시터 진단장비의 최대 7 종류의 데이터 를 모니터링 할 수 있고 이 중 최대 3 개의 데이터를 그 래프로 표현해 줄 수 있으며 데이터의 종류, 스케일, 그 래프의 색상 등을 설정해 줄 수 있다.

\section{4. 실험장치의 구성 및 결과고찰}

\section{1 실험장치의 구성}

알루미늄 전해 커패시터의 $\mathrm{ESR}$ 검출에 대하여 본 연구에서 수행된 진단 알고리즘의 전체 시스템을 그림 6 과 같이 구성하 여 실험을 수행하였다. 진단을 위한 커패시터 관련 구성회로는 그림 6과 같이 승압형(boost) $\mathrm{DC} / \mathrm{DC}$ 컨버터를 구성하여 다이 오드 정류부의 $\mathrm{DC}$ 링크 커패시터 및 $\mathrm{DC}$ 출력부의 평활용 커 패시터에 대하여 진단을 수행하도록 하였다. 두 종류의 커패시 터에 대한 $\mathrm{ESR}$ 을 추정하기 위하여 그림 2 의 알고리즘에 기반하 여 커패시터의 맥동 성분을 각 검출하였으며 이는 $V_{C, \text { Ripple }}$ 및 $I_{C, \text { Ripple }}$ 로 표현하였다.

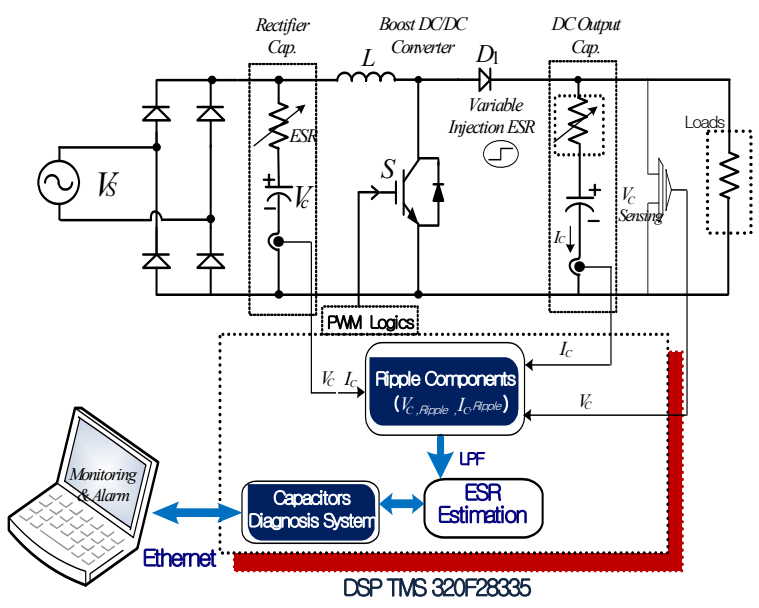

그림 $6 \mathrm{ESR}$ 추정을 위한 진단시스템의 전체 구성도

Fig. 6 Overall configuration of diagnosis system for ESR estimation.

이때의 추정하고자 하는 $\mathrm{ESR}$ 값은 커패시터의 내부 파라 미터를 가변하기 어려우므로 외부에서 커패시터와 $1[\Omega]$ 의 저항을 직렬로 연결되어 스위칭 하도록 하였으며 이때의 실 험조건은 다음과 같이 설정하였다.

- (단상) 전원 $V_{S}=56\left[\mathrm{~V}_{\text {peak }}\right] 60[\mathrm{~Hz}]$, 부하저항 : $300[\Omega]$

- 정류기 커패시터 : $400[\mathrm{VW}], 1,000[\mathrm{uF}] * 2$ 개 병렬

- $\mathrm{DC}$ 출력 커패시터 : 450[VW], 2,400[uF] 1 개

- $V_{I N}$ (정류기) 및 $V_{C}$ 커패시터 : $6,800[\mu \mathrm{F}]$ 및 $4,700[\mu \mathrm{F}]$

- DC Link : 78.4[V], 승압전압 : 163[V]

- IGBT 스위칭 주파수 : $5[\mathrm{kHz}]$, 듀티비 :0.5

그림 7과 커패시터 진단 시스템의 전면부 및 내부 모습을 나타내는 사진이다. 내부의 모습에서 아랫부분의 큰 보드는 TMS 320F28335의 DSP 보드를 나타내고 그 위의 적은 보 드는 Color TFT-LCD에 대한 표시 기능을 담당하는 프로 세서 보드로 STMicro사의 Cortex-M3계열의 ARM프로세서 인 STM $32 \mathrm{~F} 107 \mathrm{VCT} 6-72[\mathrm{MHz}]$ 의 보드를 나타내고 있다.
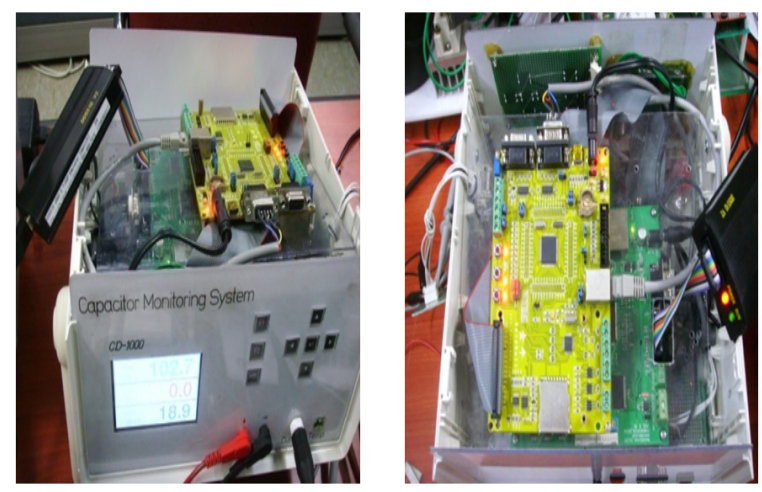

그림 7 커패시터 진단 시스템의 전면부와 내부 모습

Fig. 7 Overall photograph of capacitor diagnosis system.

\section{2 실험결과 및 고찰}

그림 8과 그림 9 는 부스트 컨버터의 정류부 $\mathrm{DC}$ 링크 커 패시터와 $\mathrm{DC}$ 출력부 필터 커패시터에 대한 $\mathrm{ESR}$ 추정에 대 한 실험 결과 파형을 각각 나타낸 것이다. 이들 그림의 순 서는 각각 커패시터를 통과하고 있는 실제의 전류 및 양단 의 전압을 그림 (a),(b)에서 나타내고 그림 (c)에서는 DC 옵 셋을 제외한 순수 리플 성분의 전류 $\left(I_{C, \text { Ripple }}\right)$ 만을 나타내고, 그림(d)에서는 $\mathrm{ESR}$ 의 추정결과를 각각 나타낸 것이다. 이때 의 추정된 $\mathrm{ESR}$ 의 결과는 약 10 초 동안에 약 2 초의 간격으 로 외부의 직렬저항 $1[\Omega]$ 을 스위칭 하도록 하여 가변 부하 저항에도 모두 주어진 알고리즘에 견실히 잘 추종하고 있음 을 보여주고 있다. 특히 위의 결과에 따라 본 연구에서 적 용한 $\mathrm{ESR}$ 의 추정 알고리즘 기법은 기존의 한정된 전력 컨 버터에만 사용되는 알고리즘과 달리 컨버터의 종류에 상관 없이 잘 적용할 수 있다는것을 알 수 있다.

그림 10은 전해 커패시터의 진단에 대한 계측값 및 진단 결과를 각각 디스플레이한 화면을 캡쳐한 사진이다. 이는 $\mathrm{ESR}$ 의 추정결과 및 커패시턴스의 용량까지 추정되도록 시 스템이 설계되어 있으며 이의 추정결과는 커패시터의 고장 진단 시스템에 사용하기에 충분하다고 판단되고 있다[8].

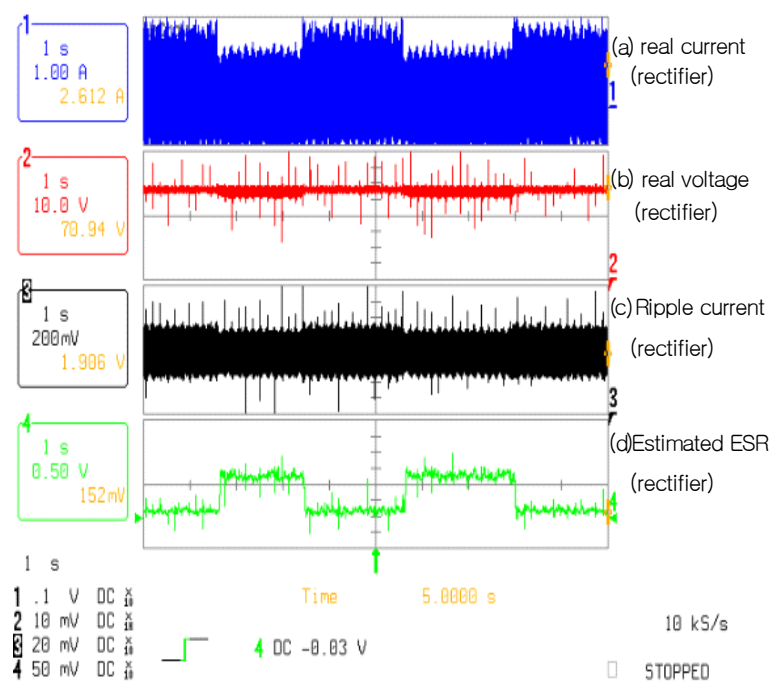

그림 8 가변 ESR의 추정결과 (DC Link Capacitor)

Fig. 8 Estimated results with the variable ESR. 


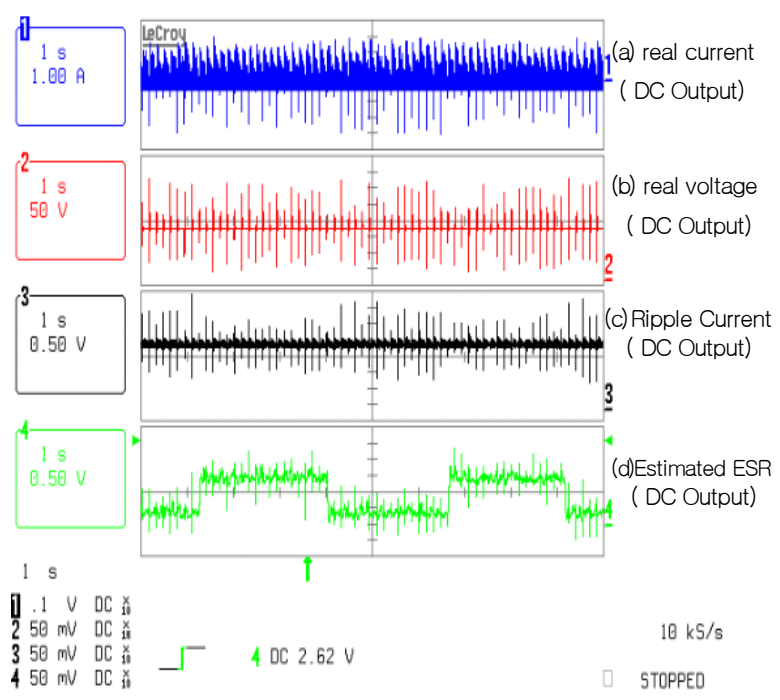

그림 9 가변 $\mathrm{ESR}$ 의 추정결과 (DC Output Capacitor)

Fig. 9 Estimated results with the variable ESR.
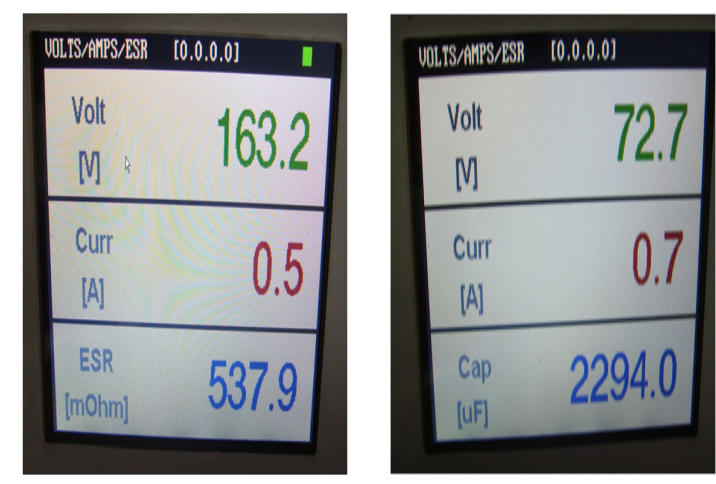

그림 10 커패시터 진단 시스템의 디스플레이 화면

Fig. 10 Display capture of capacitor diagnosis system.

\section{5. 결 론}

가격 및 대용량의 장점 때문에 다양한 전력 변환장치에 주로 사용되고 있는 전해 커패시터는 사용시간의 증대에 따 른 전기화학적 열화의 특성 때문에 빈번한 손상 및 고장을 일으키는 사고요인으로 작용한다. 따라서 이의 사고에 대한 예방진단 및 지속적인 모니터링 감시 장치가 필요하다.

본 논문에서는 전해 커패시터의 고장 검출을 위한 $\mathrm{ESR}$ 의 추정을 위하여 커패시터 맥동 성분의 전압 및 전류로부터 전력손실의 개념을 도입하여 별도의 $\mathrm{BPF}$ 의 구성없이 간단 하게 $\mathrm{ESR}$ 값을 추정할 수 있는 진단기법을 적용하여 시스 템을 구성하였다. 특히 본 연구에서는 고성능의 $\mathrm{DSP}$ 를 적 용하여 LAN기반의 이더넷 원격 네트워크 통신시스템을 구 축하여 고장신호의 검출 데이터를 인터넷에 연결되어 있는 서버에서 원격으로 모니터링 및 상태를 감시할 수 있도록 성능을 개선하였다. 따라서 개발된 본 진단시스템은 다양한 전력변환장치에 범용적으로 활용 가능하여 커패시터 부품의 열화에 따른 전기적 사고 예방에 기여할 수 있으리라 판단 된다.

\section{감사의 글}

이 연구는 2011학년도 경원대학교 지원(KWU-2011-R151) 에 의한 결과이며 또한 지식경제부(에기평)의 2011년도 '전력 산업연구개발사업'의 연구 지원에 의하여 연구 수행된 내용 의 일부임

$$
\text { 참 고 문 헌 }
$$

[1] United States Department of Defense, "US MIL -HDBK-217F Reliability Prediction of electronics Equipment," Version F, Notice 2, USA, 1995.

[2] 기술표준원 신뢰성전문위원회, "알루미늄 전해 커패시 터 해설서 RS C 0005", 산업자원부, 2001년 11월.

[3] Afroz M. Imam, Thomas G. Habetler, Ronald G. Harly and D. M. Divan, "LMS based Condition Monitoring of Electrolytic Capacitor" IEEE Trans. on Ind. Appl., vol., 41, no.6 ,pp.848-853, 2005.

[4] D. -C. Lee, K.-J. Lee, J.-K. Seok and J.-W. Choi, "Online capacitance estimation of DC-link electrolytic capacitors for three-phase $\mathrm{AC} / \mathrm{DC} / \mathrm{AC} \mathrm{PWM}$ converters using recursive least squares method", IEE Proc.-Electr. Power Appl., Vol. 152, No.6, november 2006.

[5] 손진근, "전력변환장치에서의 $\mathrm{DC}$ 출력 필터 커패시터 의 온라인 고장 검출기법", 전기학회 논문지, 제 $58 \mathrm{P}$ 권 제4호, pp. 483-489, 2009년 12월.

[6] 손진근, 나채동, "PWM 전력 컨버터에서 $\mathrm{DC}$ 링크 커 패시터의 개선된 온라인 고장 진단", 전기학회 논문지, 제59P권 제1호, pp. 40-46, 2010년 3월.

[7] P. Venet, F.Perisse, M.H. El-Hussein1 and G. Rojat, "Realization of a smart electrolytic capacitor circuit", IEEE of Industry Applications Magazine, No.1, pp. 16-20. 2002.

[8] 손진근, 김동준, "전력변환기에 대한 직류링크 커패시터 의 고장진단을 위한 간단한 용량 추정 기법", 전기학회 논문지, 제60P권 제4호, pp. 378-38346, 2010년 12월.

[9] E.C. Aeloiza, J.H .Kim, P. Ruminot and P.N Enjeti, "A Real Time Method to Estimate Electrolytic Capacitor Condition in PWM Adjustable Speed Drives and Uninterruptible Power Supplies," in Conf. Rec. IEEE 2005 PESC, pp.2867-2872.

[10] Matsushita Electronic Components Co, "Technical guide of aluminum electrolytic capacitors," Mar. 2, 2000.

저 자 소 개

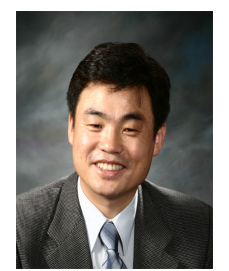

\section{손 진 근 (孫 珍 劤)}

1990년 숭실대학교 전기공학과 졸업. 1992/1997 년 동 대학원 전기공학과 졸업(석사/박사). 1992 1995 현대중공업(주) 기전연구소 주임 연구원. 2002. 2 2003. 2 (한국과학재단) 일 본 가고시마대학 전기공학부 Post-doc. 2009. 1 2010. 2 Michigan State University 방문 교수. 현재, 경원대학교 전기공학과 교수.

Tel : 031-750-5711, Fax : 031-750-5354 E-mail : shon@kyungwon.ac.kr 